\title{
Technology Andragogy Work Content Knowledge Model as a New Framework in Vocational Education: Revised Technology Pedagogy Content Knowledge Model
}

\author{
Zainal Arifin ${ }^{1}$, Muhammad Nurtanto ${ }^{2}$, Asep Priatna ${ }^{3}$, Nur Kholifah ${ }^{4}$, Moh Fawaid ${ }^{2}$ \\ ${ }^{1}$ Department of Automotive Engineering Education, Yogyakarta State University, \\ Jl. Colombo No.1, Yogyakarta, Indonesia \\ ${ }^{2}$ Department of Mechanical Engineering Education, Universitas Sultan Ageng Tirtayasa, \\ Jl. Raya Jakarta Km 4, Banten, Indonesia \\ ${ }^{3}$ Department of Primary Teacher Education, STKIP, l. Marsinu No.5, Dangdeur, Kec. Subang, Indonesia \\ ${ }^{4}$ Department of Culinary and Fashion Education, Yogyakarta State University, Jl. Colombo No.1, \\ Yogyakarta, Indonesia
}

\begin{abstract}
Nowadays, the ICT is an important part of the 21st century and teacher learning and industry 4.0 challenges must involve technology in their teaching and learning. Previous research on the involvement of technology in the learning process is generally known as TPACK, Technology - Pedagogy Content - Knowledge. However, the specific objectives of implementing vocational learning are specific to certain occupations. The purpose of this study is to analyse the teaching and learning needs of students in professional vocational education with the revised TPACK new model approach. The study of qualitative methods in the form of document analysis is used to construct a new theoretical conceptual framework. Important findings offered in the concepts of teaching and learning of vocational students were adopted based on work, content, technology, and learning approaches which were conceptualized as TAWOCK.
\end{abstract}

DOI: $10.18421 /$ TEM92-48

https://doi.org/10.18421/TEM92-48

Corresponding author: Muhammad Nurtanto,

Universitas Sultan Ageng Tirtayasa-Jl. Raya Jakarta Km 4, Banten, Indonesia.

Email: mnurtanto23@untirta.ac.id

Received: 03 February 2020.

Revised: 29 April 2020.

Accepted: 05 May 2020.

Published: 27 May 2020.

(cc)BY-NC-ND(C) 2020 Muhammad Nurtanto at al; published by UIKTEN. This work is licensed under the Creative Commons Attribution-NonCommercial-NoDerivs 4.0 License.

The article is published with Open Access at www.temjournal.com
The work as a new domain shows the characteristics of student teaching and learning while the learning approach has shifted from the level of engagement Pedagogy to the level of cultivation - Andragogy. The study explains that vocational education with the TAWOCK concept is an ideal model for developing depth.

Keywords - TPACK, TAWOCK, teaching and student learning, vocational education, andragogy learning

\section{Introduction}

The current world education trend is a teaching and learning of technology-based students [1], [2]. However, the developers renewed the concepts of learning that lead to online learning. In fact, this concept is considered new from previous learning, namely conventional. Thus, researchers recommend the role of technology in online learning to make a positive contribution [3], namely, motivation, interest, innovation, and attitudes, knowledge and skills competencies have increased. However, environmental resources are important and influential in determining success factors.

In line with the challenges of the 21 st century learning, aim at life skills and care skills, learning and innovation skills, and information, media, and technology skills [4], to become effective when human resources are formed. This goal is in accordance with the implementation of vocational education in equipping certain competencies to support themselves and their families. Previous research findings recommend that TPACK is used in teaching and learning [5]. The results of the study, have a positive impact on learning. However, the argument arises that TPACK is an approach and vocational education is the target of learning. So a literature review is needed to assess the suitability of 
TPACK in vocational education. The research objective to be achieved is what conceptual model is in accordance with the understanding of knowledge in vocational education.

\section{Literature Reviews}

The TPACK is an interesting conversation in vocational education in bringing together the concept of knowledge in specific expertise. TPACK is considered general, more directed to the approach of science education [6], [7], without seeing the appropriate and specific work competence. The change in the TPACK model [8], from the PCK model [9], is a form of rapidly changing scientific discipline that is the emergence of technological dominance into pedagogy knowledge. Likewise, similar approaches need to be taken in the fields of vocational work orientation but do not change the original TPACK. This, based on the domain elements and factors of change considered, needs to be discussed to avoid understanding bias.

\subsection{TPACK in Knowledge on Learning and Teaching}

The success of teaching and learning in the field of science education is inseparable from the chosen approach model. Most researchers involve TPACK as a good alternative approach to integrating technology-pedagogy-andragogy-content knowledge and success in achieving learning outcomes. TPACK puts forward technology domain in understanding learning. So that students feel the situation is new, interesting, and effective [10]. Even though, the critical success factor is also influenced by the characteristics of the students. Some TPACK research models have been applied in the field of vocational education [11]. However, the essence of the competencies achieved is still biased between the interests of learning to the needs of the industry. Even the needs of industry are the main goal of the implementation of education, namely education for work and specific work [12]. The following are the original TPACK models developed [13].

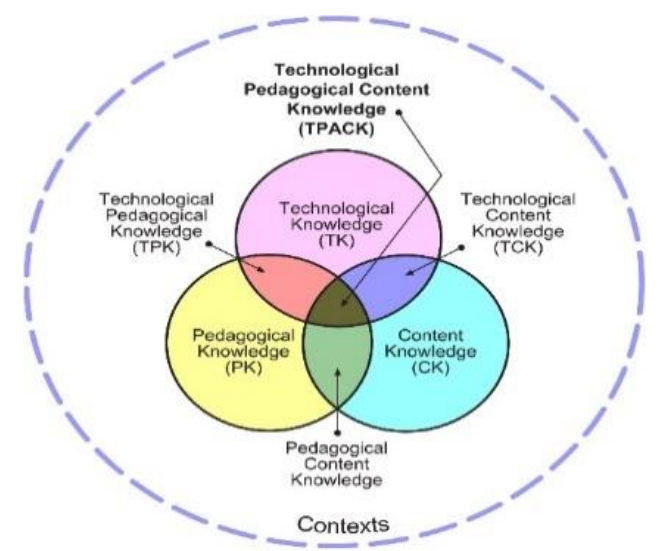

Figure 1. TPACK framework. The graphic used with permission from http://tpack.org/
The TPACK learning model, also called the TPCK model, is a change from the PCK model developed by Shulman [14]. The initial purpose of the TPACK model concept was used to stimulate teachers in shaping their knowledge by integrating technology, pedagogy, and content according to the education curriculum [15], [5]. Many ICT researchers have adopted this model [16], [17]. Vent diagrams (Pict. 1) Describe TPACK of 2 parts, 3 parts, and the relationship of 4 parts. The diagram, used in the concept of Context in vocational education. So that TPACK is used according to the learning and teaching needs of educators. Although many researchers use the TPACK model and lose the direction of each element formed.

The researcher recommends that the TPACK model is the right choice in learning science. While there is debate when the model is adopted in vocational education, vocational education must be as close as possible to the needs of the workforce [18]. It should be a liaison between the needs of work competencies and educational institutions. This is seen as effective when applied to education and training providers. Then there is an increase in the dominance of the context taught. The intended dominance is the "Work" domain that becomes the main element before the model is adapted. In addition, there is a domain that must be increased in its level, namely the level of engagement into cultivation "andragogy" which is discussed in a philosophical approach to vocational education and theory of learning approaches used in vocational education or TVET [19], [20].

\subsection{Work Domains Adopted Into the New Model}

Vocational education or vocational education is education for the world of work. Billet as a vocational expert defines it as an education for occupation [12]. Vocational education must be able to equip students' skills to enter the workforce [21]. The final estuary of vocational education is occupations or competencies according to their work. BNSP describes it in the form of KKNI as a reference and is repackaged into a specific job or occupation as a competency. In a hierarchy, competence is born from schemes and clusters (general in nature). For example, the field of automotive expertise consists of several clusters, namely Light Vehicle Engineering (Wheel 4), Motorcycle Engineering (Two-Wheel), and body repair cluster (adapted from http://lsptop.co.id/). While understanding the test scheme is more specific to one cluster [22].

a. Cluster of four-wheeled vehicles

1) Engine tune-up conventional

2) Engine tune-up injection system 
3) Maintenance of exhaust emissions

4) Maintenance of four-wheel alignment

5) Maintenance and repair of manual brake systems

b. Cluster of two-wheeled motorcycle

1) Motorcycle service of carburetor system

2) Motorcycle service of injection system

c. Cluster of body repair on vehicle

1) Making vehicle body color mixture paint

2) Painting the vehicle body

3) Repair the vehicle body panel

Each scheme consists of several jobs called competency units. The unit determination consists of general work, specific expertise, recording, and reporting carried out with several mixed methodological concepts. Among them are interviews, practical observations, written and oral tests, and RPL [23]. Thus that the field of work in vocational education involves several subcompetencies to carry out certain occupational clusters. This is the author's consideration that the addition of work domains is needed in accordance with the work cluster or work scheme chosen.

The dominance of work knowledge (WK) merges with the dominance of content knowledge and technological knowledge. Content knowledge in educational providers is based on a reference to outcome competency standards (SKL) as a target output, the context in the area of expertise, the input is students, the process consists of curriculum, teaching materials, subjects, etc. All areas of expertise in vocational education have the same characteristics.

\subsection{Improvement of Pedagogical domain (engagement) to Andragogy domain (cultivation)}

Learning of the 21 st century in vocational education leads to career skills and development jobs at a better level. Thus, the praxis of teaching and learning adjusts to changes in the world of work. Vocational education providers will be left behind or graduates will not be able to compete if they do not follow trends in vocational training. Teaching and learning require a learning approach that is able to keep up with change.

In the original model, pedagogy is the chosen learning model approach. Whereas the vocational learning approach is recommended to have three levels with the term tri-gogy [20]. The first level is called engagement-pedagogy. The second level is called culmination-andragogy. The third level is called realization-heutagogy. Pedagogy level is a learning approach with a level below or basic. At this level, students are participants who follow the will of educators. The claim of pedagogy is the lack of freedom to develop into an adult and independent, rigid, and procedural so that it feels unproductive. The next level is andragogy emphasized maturity and independence in learning. This is the formation of controlled consciousness. This context is more suited to conditions of unstable change needed by life skills, career skills with information technology, and communication media. Researchers recommend a shift in the level towards a higher direction, namely pedagogy to andragogy. While the highest level is realization-heutagogy, which is learning more than the demands of adults with the principle of being a part of life. A description of the level of learning approaches in vocational education is presented in Figure 2.

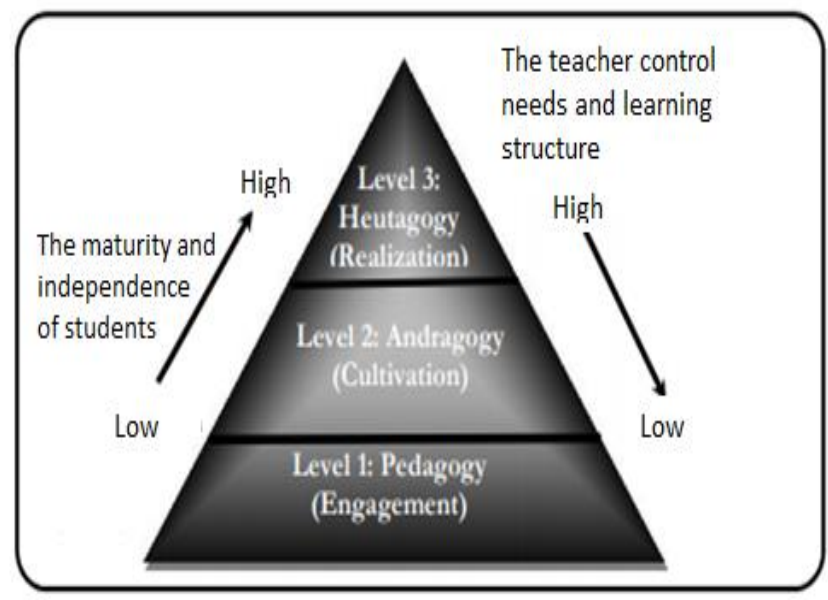

Figure 2. Level of Learning Approaches between Pedagogy, Andragogy, Heutagogy [19]

The description that has been explained by the addition of the work domain and increased domain of andragogy is characteristic of the new model for vocational education. Meanwhile, other attributes such as technology knowledge, and content knowledge remain the same. Researchers concocted all dominions as TAWOCK in the context of vocational education tailored to the area of expertise.

\section{Research Methods}

The research concept was carried out in the stages of evaluating knowledge in vocational education that had applied TPACK or PCK. The evaluation approach is carried out with two points of view, namely goal-oriented in the work field or work domain and the learning approach chosen. A literature review is needed to propose a conceptual model that fits the characteristics of vocational education. A central position in developing theory and evaluating practical problems [24], uses a conceptual framework model in answering research problems, describing phenomena, and analyzing existing structures. Conceptual framework forms 
include a set of constructions in phenomena and artifacts that are appropriate to the context of the problem. The context of the problem referred to by the researcher in the evaluation of the TPACK framework from the perspective of vocational education.

\section{Modify the TPACK Framework to be the New TAWOCK Framework}

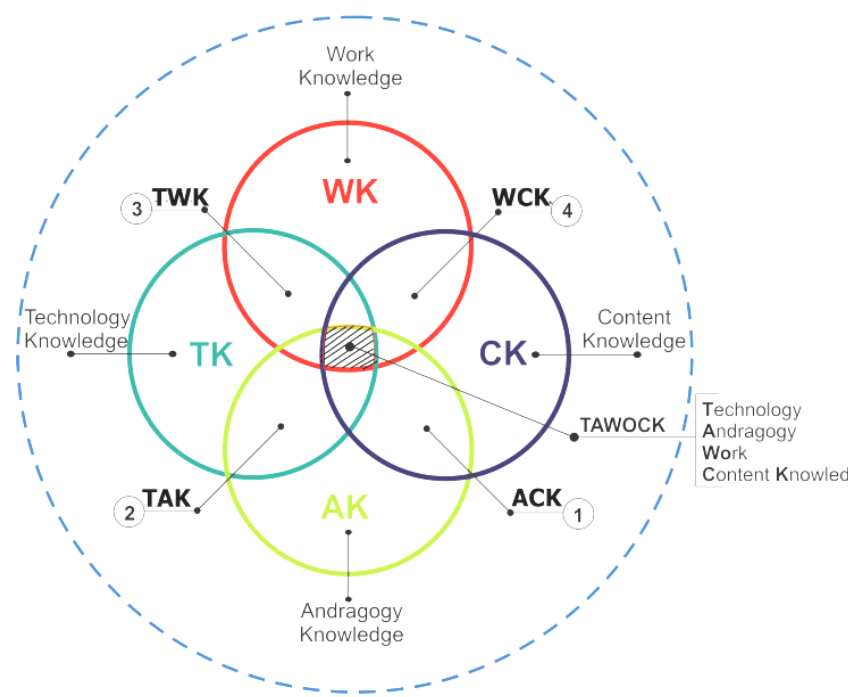

Figure 3. TAWOCK Framework for Vocational Education

\subsection{TAWOCK Framework}

The TAWOCK conceptual model is an integrated relationship between the work context or specific area, the content delivered, the technology needed, and the learning approach adapted. Educators in implementing TAWOCK are a form of professional expertise in learning. The consideration is that the ability of each educator is diverse and the challenge of educators is knowledge of the elements effectively.

\subsection{The Concept of 2-area Overlap (WK-CK-AK- TK)}

The Work Knowledge (WK) refers to an understanding of work understanding in the vocational field which is distributed to separate competencies in facilitating mastery at the learning stage. For example, a professional teacher in the field of automotive engineering is his ability to understand the work carried out by technicians or interpreters in expertise or competence according to division. The scope of the automotive field and in the light vehicle engineering sector (four wheels) is still divided into three scopes, namely the engine, electrical, body and chassis. Because the context of learning is to prepare students in work knowledge, the competencies in each scope must be understood and mastered as a whole. In the context of the integration of work in the industry, the most commonly performed are KKNI standards such as tune-up engines, brake system repairs, and other jobs. Educators lose the concept if the WK element is not understood or has never been directly involved. The impact, the graduate output is not absorbed in the industry.

The Content Knowledge (CK) is the basis in determining curriculum or material taught in vocational education. This relates to theoretical concepts, conceptual and contextual knowledge to knowledge in skills. The knowledge content of the curriculum is translated into related teaching materials, work instructions, worksheets, assessments. Context deviations are knowledge that is narrow or broad from the focus of competence. Generally caused by the experience of limited fieldwork abilities (technical ability) and methodological mastery (the ability of ways). Planning for content knowledge is carried out for the effective and efficient use of time.

The Andragogy Knowledge (AK) is the educator's understanding of appropriate learning approaches in teaching and learning in vocational education. Andragogy is the second level after pedagogy and heutagogy which is referred to in the term Tri-Gogy. The learning approach develops in the direction of learning and job needs in the workplace. Learning in vocational education has experienced an expansion that leads to students as active sources. So pedagogy at a basic level (engagement) that is learning between educators and students does not provide freedom of tenancy, independence, determination of attitude, tends to be rigid, procedural, and less efficient [20]. So level 2, called cultivation or acquisition of student competencies are needed. Cultivation learning leads to the characteristics of students by utilizing various sources to achieve learning objectives. Furthermore, this second level is referred to as andragogy. The concept of this learning approach fulfills the characteristics of vocational education.

The Technology Knowledge (TK) is an understanding of educators and students in utilizing technology resources to achieve learning objectives. In the learning process educators and students must be able to use all the potential of technology. In the context of work, students are taught in current developments. Sources that can be used can be obtained by ICT and the most important is understanding in analyzing the truth of sources.

\subsection{Concept of 3-area overlap(WCK-ACK-TAK- TWK)}

Work Content Knowledge (WCK) is multilevel knowledge or a combination of productive work knowledge and content knowledge [25]. The WCK is knowledge of how to arrange, develop and apply 
knowledge of how content about work [26], in certain fields is sorted and organized in support of competencies that are easily understood by students. The WCK is closer to the needs of the industry or the world of work, more often the concept is developed by the Education and Training Center which prepares graduates to work. However, the industry is more specific than the competencies taught in vocational education institutions. While the concept needed is the amount of practice content more than theory. Educational institutions provide diverse competency content intended to equip students to be able to work in various fields by providing broad opportunities. However, control of competency mastery often occurs. The WCK is located as a trigger between industry and education providers to produce the competencies needed in the world of work.

The Andragogy Content Knowledge (ACK) is knowledge related to andragogy and content [27], [28]. Andragogy is a new concept that is derived from the previous concept of revised pedagogy [29]. Strong consideration that pedagogy has strong characteristics of educators as a source of knowledge and passive students in teaching and learning. Vocational students are required to be able to determine their choices and occupations. So that vocational decision making affects the career path. The behavior approach achieved is independence, responsibility, discipline, and others. This is the basis for taking the second level after offering pedagogy, namely andragogy. Students in vocational education are more directed towards adult education because of their chosen responsibilities and career paths. The ACK is knowledge about how competence is taught while students can master it. The variation of learners becomes a challenge for educators in managing learning strategies. Even so, making students active with the development of information that is fast and can account for the concept of knowledge chosen.

The Technology Andragogy Knowledge (TAK) is a role in the use of technology to support student psychology in achieving competence with adult methods and technology [30]. Among them, distinguish primary and secondary sources that can be trusted. This is more the analytical ability of students constructed. However, educators play a role as controls in controlling free technological knowledge.

The Technology Work Knowledge (TWK) is the ability to understand, analyze, and apply techniques used in the workplace. Industrial development is faster than technology, vocational education providers. This is a limitation in producing competent graduates. However, technology in the workplace must be well introduced. In fact, the output of many vocational education institutions took courses in education and training with better equipment capabilities. TWK must be delivered properly in the development of technology in the field of work.

\subsection{Concept of 4-area Overlap (TAWOCK)}

Hierarchy Shulman is known as pedagogical content knowledge (PCK). Furthermore, the Hierarchy [13], modified and substituted technology knowledge into PCK which is known to date with TPACK. However, this is a general hierarchy of knowledge. This means that for specific education content knowledge it is still unclear. So that researchers in this perspective adapt and develop TPACK with their work or referred to as new hierarchy, namely the work knowledge of content andragogy and technology (TAWOCK) as a hierarchy of new knowledge in vocational education.

This knowledge is a combination of field interactions, namely $\mathrm{WK}, \mathrm{CK}, \mathrm{AK}$, and $\mathrm{TK}$ as a reference to work competencies taught in vocational education. However, knowledge is influenced by many factors such as students, educators, content, competence, and technology.

\section{Conclusion}

This research has produced a conceptual framework in the form of new models in more specific vocational education. This research connects theoretical studies related to work knowledge and knowledge of andragogy as an additional domain. TAWOCK as a new model modified from the TPACK model in the context of vocational education. New dominance was formed, among others, WorkContent-Andragogy-Technology. New domes added and upgraded to the next level are supported by relevant sources. Furthermore, the TAWOCK model needs to be empirically tested.

\section{References.}

[1]. Ahmadi, S., Keshavarzi, A., \& Foroutan, M. (2011). The Application of Information and Communication Technologies (ICT) and its Relationship with Improvement in Teaching and Learning. Procedia Social and Behavioral Sciences, 28, 475-480. https://doi.org/10.1016/j.sbspro.2011.11.091

[2]. Akir, O., Eng, T. H., \& Malie, S. (2012). Teaching and Learning Enhancement Through Outcome-Based Education Structure and Technology e-Learning Support. Procedia - Social and Behavioral Sciences, 62, 87-92.

[3]. Costley, K. C. (2014). The Positive Effects of Technology on Teaching and Student Learning. Online Submission.

[4]. Trilling, B., \& Fadel, C. (2009). 21st century skills: Learning for life in our times. John Wiley \& Sons. 
[5]. Voogt, J., \& McKenney, S. (2017). TPACK in teacher education: Are we preparing teachers to use technology for early literacy?. Technology, pedagogy and education, 26(1), 69-83.

https://doi.org/10.1080/1475939X.2016.1174730

[6]. Kafyulilo, A., \& Fisser, P. (2019). Developing TPACK in Science and Mathematics Teacher Education in Tanzania: A Proof of Concept Study. In J. Pieters, J. Voogt, \& N. Pareja Roblin (Eds.), Collaborative Curriculum Design for Sustainable Innovation and Teacher Learning (pp. 139-155). Springer International Publishing. https://doi.org/10.1007/978-3-030-20062-6_8

[7]. Resbiantoro, G. (2017). Self-Efficacies of Prospective Mathematic Teachers' Technological Pedagogical Content Knowledge (TPACK). Jurnal VARIDIKA, 28(2), 102-115.

[8]. Koehler, M. J., Mishra, P., Kereluik, K., Shin, T. S., \& Graham, C. R. (2014). The Technological Pedagogical Content Knowledge Framework. In J. M. Spector, M. D. Merrill, J. Elen, \& M. J. Bishop (Eds.), Handbook of Research on Educational Communications and Technology (pp. 101-111). Springer New York.

https://doi.org/10.1007/978-1-4614-3185-5_9

[9]. Suh, J. K., \& Park, S. (2017). Exploring the relationship between pedagogical content knowledge (PCK) and sustainability of an innovative science teaching approach. Teaching and Teacher Education, 64, 246-259.

https://doi.org/10.1016/j.tate.2017.01.021

[10]. Yuenyong, C., \& Thongnoppakun, W. (2019). Preservice Science Teachers' Professional Learning Through Content Representations (CoRes) Construction. Journal for the Education of Gifted Young Scientists, 7(4), 1263-1275.

[11]. Chua, J. H., \& Jamil, H. (2012). Factors Influencing the Technological Pedagogical Content Knowledge (TPACK) among TVET instructors in Malaysian TVET Institution. Procedia - Social and Behavioral Sciences, 69, 1539-1547.

[12]. Billett, S. (2011). Vocational education: Purposes, traditions and prospects. Springer Science \& Business Media.

[13]. Mishra, P., \& Koehler, M. J. (2006). Technological Pedagogical Content Knowledge: A Framework for Teacher Knowledge. Teachers College Record, 108(6), 1017-1054.

[14]. Shulman, L. (1987). Knowledge and Teaching: foundations of the new reform. Harvard Educational Review.

[15]. Tanak, A. (2018). Designing TPACK-based course for preparing student teachers to teach science with technological pedagogical content knowledge. Kasetsart Journal of Social Sciences.

[16]. Baran, E., Canbazoglu Bilici, S., Albayrak Sari, A., \& Tondeur, J. (2019). Investigating the impact of teacher education strategies on preservice teachers' TPACK. British Journal of Educational Technology, 50(1), 357-370. https://doi.org/10.1111/bjet.12565
[17]. Bostancığlu, A., \& Handley, Z. (2018). Developing and validating a questionnaire for evaluating the EFL 'Total PACKage': Technological Pedagogical Content Knowledge (TPACK) for English as a Foreign Language (EFL). Computer Assisted Language Learning, 31(5-6), 572-598. https://doi.org/10.1080/09588221.2017.1422524

[18]. Akoojee, S. (2019). Informal Economies, WorkBased Learning and Sustainable National Skills Development in Africa. In S. McGrath, M. Mulder, J. Papier, \& R. Suart (Eds.), Handbook of Vocational Education and Training: Developments in the Changing World of Work (pp. 1-19). Springer International Publishing.

[19]. Blaschke, L. M. (2012). Heutagogy and lifelong learning: A review of heutagogical practice and selfdetermined learning. The International Review of Research in Open and Distributed Learning, 13(1), 56-71.

[20]. Sudira, P. (2017). TVET Abad XXI: Filosofi, Teori, dan Strategi Pembelajaran Vokasional. UNY Press.

[21]. Pavlova, M. (2014). TVET as an important factor in country's economic development. SpringerPlus, 3(Suppl 1). https://doi.org/10.1186/2193-1801-3-S1$\underline{\mathrm{K} 3}$

[22]. Nurtanto, M., Sofyan, H., Pardjono, P., \& Suyitno, S. (2020). Development Model for Competency Improvement and National Vocational Qualification Support Frames in Automotive Technology. International Journal of Evaluation and Research in Education, 9(1), 168-176.

[23]. OECD. (2017). Making Integration Work: Assessment and Recognition of Foreign Qualifications. OECD Publishing.

[24]. Wieringa, R. J. (2014). Design science methodology for information systems and software engineering. Springer.

[25]. Pyöriä, P. (2005). The concept of knowledge work revisited. Journal of knowledge management. https://doi.org/info:doi/10.1108/13673270510602818

[26]. Moussa, M., Bright, M., \& Varua, M. E. (2017). Investigating knowledge workers' productivity using work design theory. International Journal of Productivity and Performance Management, 66(6), 822-834.

[27]. Crawford, C. M., Young Wallace, J., \& White, S. A. (2018). Rethinking Pedagogy, Andragogy and Heutagogy. Academic Exchange Quarterly, 22(4).

[28]. Krajnc, A. (1989). Andragogy. In C. J. Titmus (Ed.), Lifelong Education for Adults (pp. 19-21). Pergamon. $\quad$ https://doi.org/10.1016/B978-0-08$\underline{030851-7.50012-6}$

[29]. Loeng, S. (2018). Various ways of understanding the concept of andragogy. Cogent Education, 5(1), 1496643.

https://doi.org/10.1080/2331186X.2018.1496643

[30]. Santos, R. (2012). Andragogy content knowledge technology: A training model for teaching adults (pp. 1-214). Arizona State University. 